\title{
ENTRAI PELA PORTA DOS FUNDOS: DEFESA DE FÉ E CRENÇAS NO CANAL NO YOUTUBE
}

\author{
Enter through the Back Door: \\ In defense of faith and beliefs on a YouTube channel \\ Entra por la Puerta de Atrás: \\ En defesa de la fe y de la crencia en el canal de YouTube
}

Tiago Barcelos Pereira Salgado
Doutor em Comunicação pela UFMG
tigubarcelos@gmail.com

Bruno Menezes Andrade Guimarães

Doutorando em Comunicação pela UFMG

brunomenezesag@gmail.com

\section{Resumo}

Investigamos as apropriações e os novos sentidos atribuídos a práticas e dogmas cristãos presentes no vídeo "Especial de Natal", publicado no canal de humor "Porta dos Fundos", no YouTube, em dezembro de 2013. Apresentamos e discutimos a relação entre crença e comicidade no intuito de apreendermos o humor e o riso como questionadores de verdades ditas absolutas. Por meio da análise do referido vídeo, identificamos alguns dogmas cristãos apropriados e ressignificados pelo canal mencionado. Voltamo-nos, também, para os comentários feitos na página oficial daquele canal, no YouTube, a fim de identificarmos diferentes expressões de opiniões, defesa de fé e crenças. Concluímos que o inquestionável é questionado por meio do humor, e que a própria condição de existência no mundo é posta em suspeita.

Palavras-chave: Canal no YouTube. Crença religiosa. Defesa de fé. Dogmas cristãos. Porta dos Fundos.

\begin{abstract}
This article investigates the appropriations and new meanings attributed to Christian practices and dogmas present in the video "Christmas Special" published in the YouTube channel "The Back Door" published in December 2013. This paper presents and discusses the relationship between belief and comicality in order to apprehend humor and laughter as questioners of said absolute truths. By analyzing the video in question, we identify some suitable and reevaluated Christian dogmas by the aforementioned channel. We also turn to comments on the official page of this channel on YouTube in order to identify different opinions, defense of faith and
\end{abstract}


beliefs. We conclude that the unquestionable is questioned through humor and the condition of existence in the world is doubted.

Key words: Christian dogmas. Defense of faith. Porta dos Fundos. Religous belief. YouTube channel.

\section{Resumen}

Investigamos las apropiaciones y los nuevos significados atribuidos a las prácticas y dogmas cristianos presentes en el video "Especial de Navidad", publicado en el canal de humor "Puerta de los Fondos" en YouTube en diciembre de 2013. Presentamos y discutimos la relación entre creencia y comicidad con el fin de aprehender el humor y la risa como interrogadores de verdades dichas absolutas. Mediante el análisis del vídeo en cuestión, identificamos algunos dogmas cristianos apropiados y reevaluados por el canal antes mencionado. También nos volvemos a los comentarios hechos en la página oficial de este canal en YouTube con el fin de identificar las diferentes opiniones, la defensa de la fe y las creencias de los usuarios y de las usuarias de internet. Llegamos a la conclusión de que la incuestionable es cuestionada a través del humor y la condición misma de la existencia en el mundo se pone en sospecha.

Palabras clave: Canal de YouTube. Creencias religiosas. Defensa de fe. Dogmas cristianos. Porta dos Fundos.

\section{INTRODUÇÃO}

Em 23 de dezembro de 2013, o canal de humor do YouTube, Porta dos Fundos, publica o vídeo Especial de Natal, paródia satírica acerca da vida e da morte de Jesus. Os usuários e usuárias podem opinar sobre o vídeo por meio dos botões "gostei” (like) e "não gostei” (dislike), como também comentar a produção. Essas são características recorrentes a vídeos e canais do YouTube, o que de imediato não justifica a importância de se pesquisar o canal e o vídeo supracitado. Contudo, quando atentamos para a classificação de Porta dos Fundos como um dos canais brasileiros no YouTube com o maior número de inscritos (14.757.810 em 27 de agosto de 2018), faz-se pertinente olhar com mais atenção tanto para as produções do canal quanto para as maneiras como usuários e usuárias são convocados a nele comentar. ${ }^{1}$

\footnotetext{
1 A classificação dos dez canais brasileiros no YouTube com mais inscritos encontra-se disponível em: <http://goo. gl/Mh6LIG>. Acesso em: 17 mar. 2016.
} 
Porta dos Fundos é uma produtora de vídeos de humor criada em março de 2012. O canal de mesmo nome no YouTube foi criado em 11 de março daquele ano e o primeiro vídeo foi publicado cinco meses depois, em agosto. De acordo com relatos dos fundadores, Antonio Tabet, Fábio Porchat, Gregório Duvivier, João Vicente de Castro e Ian Fernandes, a ideia inicial era "levar para a internet um humor de qualidade e livre de censuras" (CASTRO, 2013). Dessa maneira, um grupo de atores, amigos entre si, reuniu-se para pensar no roteiro e na montagem dos vídeos, todos com tônica de humor crítico e, na medida do possível, polêmico. A ideia funcionou e, logo nos seis primeiros meses de existência, mais de trinta milhões de visualizações foram registradas no canal no YouTube.

Em 2016, Porta dos Fundos se tornou o quinto canal de comédia mais influente e o $18^{\circ}$ mais acessado em todo o mundo. ${ }^{2}$ Os vídeos são postados três vezes por semana e estão disponíveis para diferentes plataformas midiáticas, aplicativos para celulares e demais aparelhos eletrônicos portáteis. Com média de quatro minutos de duração, o humor questionador de temas cotidianos é assistido semanalmente por milhões de pessoas.

O canal Porta dos Fundos integra o "Programa de parceiros do YouTube", que possibilita a monetização de conteúdos diversos produzidos por criadores, a partir de anúncios, assinaturas e mercadorias. Os parceiros do programa são beneficiados com a expansão do potencial de lucratividade; flexibilidade de veiculação de conteúdos, ou seja, distribuição de vídeos sem restrição de plataformas de alocação de conteúdos audiovisuais; e monitoramento e gerenciamento de desempenho (YOUTUBE, 2015). Segundo a consultoria Millward Brown Vermeer, a marca Porta dos Fundos tem valor de mercado estimado em R\$ 500 milhões. O lucro do ano de 2015 é estimado em R\$ 35 milhões (MIDIAMAX, 2015). Segundo o site Social Blade, ${ }^{3}$ o ganho mensal estimado de "Porta dos Fundos" está entre R\$ 19 mil e R\$ 863 mil.

Para além dos dados estatísticos mencionados, Porta dos Fundos configura um objeto peculiar em função das diversas temáticas que são abordadas: cotidiano, economia, política, sexualidade e religião. O que chama nossa atenção e reforça o nosso interesse em investigá-lo são as críticas às práticas contemporâneas e aos dogmas da religião cristã. Em vista disso, procuramos compreender de quais maneiras públicos distintos expressam crenças - religiosas ou não - e defesa de fé em comentários sobre o vídeo mencionado em função da apropriação

\footnotetext{
${ }^{2}$ Dados disponíveis em: <http://goo.gl/vaf3vG>, <http://zip.net/bsrnDT> e <http://goo.gl/7dxXJB>. Acessos em: 27 ago. 2018.

${ }^{3}$ Disponível em: <https://socialblade.com/>. Acesso em: 27 ago. 2018.
} 
de dogmas cristãos apresentados de maneira cômica. Desse modo, interessa-nos: identificar quais dogmas da religião cristã são apresentados no vídeo; caracterizar como tais dogmas são apresentados por Porta dos Fundos e caracterizar como os públicos expressam suas crenças e defendem a fé nos comentários acerca do vídeo.

Primeiramente, realizamos um breve histórico do cristianismo em conjunto com as noções de crença e riso. Em seguida, procedemos à análise do vídeo Especial de Natal a fim de assinalarmos as expressões de defesa de fé e de crenças religiosas presentes no material audiovisual por meio da transcrição de alguns trechos dessa produção audiovisual. Após, analisamos os comentários mais expressivos de usuários e usuárias ao vídeo em questão com a mesma finalidade, com o auxílio da ferramenta de análise textual "árvore de palavras" disponível pelo software NVivo 10, que permite identificar as principais palavras utilizadas em um texto e suas relações em uma frase. Por fim, sugerimos alguns tensionamentos existentes entre as noções de dogma, crença e fé evidenciados no vídeo analisado, o que aponta para a relativização da noção de verdade diante da liberdade de expressão dos públicos intrínseca ao YouTube.

\section{CRISTIANISMO, CRENÇA E RISO}

O cristianismo é uma religião monoteísta baseada na crença em Jesus (o Cristo) como o filho de Deus que viveu em forma humana e como único e suficiente salvador da humanidade. A fé, base desta religião, fundamenta-se na ideia de que Jesus voltará para buscar aqueles que creem em seu nome, a fim de que vivam eternamente junto a ele e aos demais salvos e salvas no "céu". Em Hebreus, um dos livros que compõe o conjunto de narrativas bíblicas, o autor define o que é a fé: “Ora, a fé é a certeza daquilo que esperamos e a prova das coisas que não vemos." (HB 11, 1).

Para os cristãos e cristãs, a Bíblia é sagrada e compreende um conjunto de dogmas a serem seguidos. Segundo o Dicionário Online de Português, dogmas são os "itens particulares mais importantes de uma determinada doutrina religiosa que se apresentam como indubitáveis ou inquestionáveis" (DICIONÁRIO, 2015). Com base nos principais dogmas cristãos, percebemos que não somente denominações pentecostais e neopentecostais são portadoras de fundamentos universais, como todo o cristianismo em si pode ser descrito como fundamentado na medida em que prega a crença em uma verdade, em um fundamento. 
Desse modo, os adeptos ao cristianismo tomam tais dogmas como verdades e regras de conduta para todos os aspectos da vida. A infalibilidade da Bíblia, a necessidade absoluta de conversão individual de todos e todas, a convicção do caráter pecaminoso do mundo e a confiança na volta de Jesus são dogmas de suma importância para a maioria dos adeptos e adeptas ao cristianismo, que devem acreditar neles e obedecê-los incondicionalmente. As principais vertentes da religião cristã são: o catolicismo, a ortodoxia oriental e o protestantismo - este último oriundo da Reforma Protestante do século XVI (CÉSAR, 2000).

Com a finalidade de compreender a noção de crença, recorremos às proposições do filósofo pragmatista norte-americano William James. Para este teórico, a ideia de crença se relaciona às noções de ação, verdade e utilidade. Segundo James (1979), cremos em verdades. A verdade, segundo a lógica pragmática, é aquilo que é útil para alguém. Neste sentido, a verdade teria uma qualidade utilitária. De modo mais claro, a verdade é útil quando ela, de fato, interfere no modo como as pessoas irão agir.

Se agimos em consonância com aquilo que acreditamos, nossas ações são pautadas por verdades nas quais acreditamos. A crença se orienta, desse modo, pela verdade. Entretanto, de acordo com James (1979), a verdade não diz necessariamente e prioritariamente do certo ou do errado. A verdade varia, como este autor nos sugere pensar, de pessoa para pessoa, por mais que possa haver semelhanças e coincidências nas expressões de crenças e verdades.

Um exemplo, conferido pelo próprio pensador e que se aproxima de nossa investigação, ajuda-nos a compreender as noções que temos pontuado até aqui. James (1979) se pergunta se é verdadeira a crença em Deus. Crer em Deus é verdadeiro, para este autor, na medida em que esta ação incide diretamente em nossa experiência no mundo. Dito de outra maneira, se crer em Deus é útil, proveitoso e bom para aqueles que nele creem, Deus é verdadeiro e crer nele é uma verdade. Conforme este raciocínio, crer em Deus implica em agir considerando a sua existência. A maneira como se age é orientada pelo fato de se acreditar que Deus existe. Por outro lado, se Deus não existisse e se acreditasse em sua inexistência, como o fazem aqueles que se nomeiam ateus, as ações no mundo se dariam, e de fato se dão, de maneiras distintas daqueles e daquelas que creem em sua existência.

De modo mais conciso, se acreditar em Deus é útil para mim e vai de acordo com outras crenças e verdades que eu possuo, Deus é verdadeiro para mim. Todavia, se a crença em Deus não implica em diferenças em minhas ações e efeitos concretos em minhas experiências com as coisas e com as pessoas no mundo, Deus não precisa ser verdadeiro para 
mim, pois ele não orienta a maneira como eu ajo ou deveria agir, como argumenta James (1979).

O engajamento de um sujeito com determinada religião diz da aceitação de dogmas capazes de reger toda uma vida, isto é, diz da maneira como este sujeito toma para si as verdades de dada religião. Para James (1979), essas verdades (dogmas) agem diretamente no comportamento das pessoas mediante a crença em um deus. Especificamente, os cristãos, seguidores de Jesus, voltam-se para a Bíblia e creem nela como portadora de ensinamentos acerca de um único Deus, soberano e criador de todos os seres.

Ao longo do tempo, tanto a tradição bíblica, quanto a instituição religiosa cristã, foram fortemente contestadas. Cabe frisar que a religião é inventada pela Igreja, enquanto instituição religiosa, durante a mescla entre ela e o Estado (romano). Na Bíblia, Jesus nunca defendeu uma religião ou sequer mencionou este termo que, portanto, o precede. Mesmo a ideia de "igreja” não se relaciona a um espaço físico, mas às próprias pessoas, como Jesus se refere ao apóstolo Pedro e mesmo a comunhão em casas de crentes (leia-se aqueles que creem em Cristo) relatada no livro Atos. Outro aspecto a ser ressaltado é que cada período da história utilizou-se de suas estratégias a fim de colocar em questão uma série de dogmas fortemente presentes na sociedade. Dentre algumas estratégias utilizadas, o humor e o riso figuraram em diversos períodos com o objetivo de cumprir um papel específico com relação ao cristianismo e à atuação de líderes religiosos (MINOIS, 2003).

A história e as investigações acerca do riso são bastante antigas. É possível dizer que ele foi apontado pela primeira vez nos escritos de Aristóteles, um dos fundadores da filosofia ocidental. Contudo, mesmo presente durante a Alta Idade Média (séculos V a XV), o riso foi oficialmente contido e combatido nessa época. A Igreja Católica considerava o ato de rir uma rebelião contra Deus e uma profanação da autoridade do clero.

$\mathrm{Na}$ visão da liderança religiosa do período, rir era uma ferramenta criada pelo diabo, isto é, uma força do mal para profanar a imagem da Igreja, a posição suprema de Deus e a ordem social dogmaticamente vigente. Visto pela Igreja como profano, o riso esteve historicamente associado a questões de cunho político-religioso e chegou a ser considerado uma possessão demoníaca no período da inquisição (MINOIS, 2003).

No início do século XX, Henri Bergson, filósofo francês, publicou um ensaio sobre a comicidade que atravessaria gerações e se tornaria uma das principais referências para os estudos acerca do riso. Em pleno século XXI, os escritos de Bergson permanecem 
proveitosos. Em linhas gerais, o autor se preocupou em indicar os componentes da comicidade em diferentes situações. O rigor científico adotado por Bergson (2004) não está preocupado com a criação de fórmulas do humor, ou seja, encerrar a invenção cômica em definições intactas. Antes de qualquer coisa, é preciso considerar o humor como um organismo vivo, mutante e principalmente de defesa.

O que pode provocar o riso? Imaginemos a cena na qual um homem caminha pela rua, tropeça em uma pedra e cai. Os passantes do local não ririam caso o homem tivesse se sentado na calçada por vontade própria. Logo, não é a mudança de condição que provoca o riso. O que o provoca é a quebra da expectativa de simplesmente andar sem cair. A este respeito, Bergson (2004) aponta que a presença de certa "rigidez mecânica", quando era de se esperar maleabilidade e flexibilidade vívida, provoca o riso. No caso em questão, uma circunstância exterior (a pedra) suscita o riso.

Um corpo rígido é sinal de um corpo adormecido, que se isola e tende a se afastar do centro comum e fervilhante de uma sociedade dinâmica. Um corpo rígido está entregue a mecanismos prontos, institucionalizados, coercitivos. Porém, a sociedade deveria intervir nisso por meio de uma repressão física, material. Em meio à presença de corpos mecanizados, isto é, de algo apegado fortemente a determinada verdade, o riso se torna um gesto social que reprime a alienação, o dogmatismo, o fundamentalismo que, se não fosse por ele, correria o risco de se isolar e se fortificar cada vez mais. O riso, então, é uma espécie de correção social que "flexibiliza enfim tudo o que pode restar de rigidez mecânica na superfície do corpo social. [...] um objetivo útil de aperfeiçoamento geral” (BERGSON, 2004, p. 15).

Sobre isso, Bergson (2004) considera que todo grupo que quer se desprender de modo valorativo de uma sociedade mais ampla, imersa em um sistema de normas institucionalizadas é levado a criar modos de questionamentos e abrandamentos da rigidez. É nesse sentido que o autor entende o riso como um "trote social" e ressalta sua função de ameaça e de potencial transformação, sempre um pouco humilhante para quem ou o que é o seu objetivo.

Em jornais, revistas, programas de televisão e rádio e, principalmente na web, o humor é um dos principais recursos empregados. O canal no YouTube, Porta dos Fundos, desse modo, produz vídeos de teor crítico para, na maioria das vezes, expor determinados problemas da sociedade ou formas rígidas de pensamento e em desacordo com o pensamento moderno, caracterizado pelo individualismo, ideais secularizados e busca por autenticidade 
(TAYLOR, 2010). O riso suscitado pelas produções do canal está próximo à ideia de "riso de defesa" destacada por Bergson (2004).

Assim, compreendemos que rir de uma produção audiovisual satírica que expõe algumas controvérsias e polêmicas do cristianismo (leia-se desacordo entre usuários e usuárias), como o vídeo Especial de Natal veiculado no canal Porta dos Fundos no YouTube, é rir também de sua própria crença, o que leva a uma série de atitudes de defesa dessa mesma crença em ambientes midiáticos online como o YouTube. Ao considerarmos, então, que os escritos de James (1969) e Bergson (2004) nos levam a considerar os modos como o canal Porta dos Fundos trabalha a questão da verdade ou dogma e do cristianismo em uma de suas produções audiovisuais, passamos neste momento à análise do vídeo Especial de Natal e à identificação das maneiras pelas quais maneiras sujeitos distintos se engajam em modos de expressão e defesa de fé e de suas crenças por meio de comentários a esse vídeo.

\section{EXPRESSÕES DE CRENÇAS RELIGIOSAS E DEFESA DE FÉ EM PORTA DOS FUNDOS}

O vídeo Especial de Natal possui 16 minutos e 41 segundos. ${ }^{4}$ No dia 27 de agosto de 2016, período de escrita e revisão deste artigo, o vídeo contava com 7.165.444 visualizações, 138.582 usuários que marcaram "gostei”, 33.970 usuários que marcaram "não gostei” e 27.748 comentários. No momento de coleta dos dados, cerca de um ano após a publicação do vídeo, mais precisamente no dia 03 de janeiro de 2015, ele contava com 26.663 comentários. Dentre este total de comentários coletados, aplicamos o filtro disponibilizado pelo próprio YouTube para visualizarmos apenas os principais, de modo que ficamos com 230 comentários. Destes, excluímos aqueles cujo conteúdo não explicitava expressão de crença ou defesa de fé. Ficamos, então, com 176 comentários, que compõem o corpus que analisamos neste trabalho.

A análise do vídeo, bem como dos comentários, segue as seguintes etapas, abordadas de modo mais detalhado a seguir:

a) Decupagem e transcrição de trechos do vídeo;

b) Identificação de dogmas cristãos presentes no vídeo;

\footnotetext{
${ }^{4}$ Disponível em: 〈https://www.youtube.com/watch?v=2VEI_tn090c〉. Acesso em: 27 ago. 2018.
} 
c) Coleta de comentários do vídeo escolhido um ano após a sua publicação;

d) Identificação de palavras-chave segundo a incidência delas nos comentários e a sua relação com o conteúdo neles tematizado.

Haja vista os dogmas religiosos cristãos historicamente constituídos, destacamos no vídeo Especial de Natal a tentativa de romper com o poder exercido pela tradição cristã no que tange aos aspectos relacionados a verdades absolutas. Selecionamos o primeiro esquete do vídeo, capaz de oferecer subsídios para a compreensão desses aspectos. A cena ocorre dentro da casa de José $[\mathrm{J}]$ e Maria [M], pais de Jesus. ${ }^{5}$ Na ocasião, também estão presentes o anjo Gabriel $[\mathrm{G}]$ - segundo a tradição bíblica, o anjo leva a mensagem à Maria, anunciando que ela seria mãe do filho de Deus -, e o próprio Deus [D], interpretado em forma humana.

Por meio de insinuações e assertivas diretas, o objetivo principal do primeiro esquete é questionar o nascimento de Cristo por uma virgem. $\mathrm{O}$ anjo Gabriel surpreende José ao dizer que procura uma virgem, que retruca ao afirmar que ele e Maria mantêm uma vida sexual ativa. Tanto Gabriel quanto Deus se surpreendem com a notícia. O fim da cena mostra José conversando com Deus e indagando-o a respeito da opinião pública referente ao fato. Notemos o diálogo final entre os personagens:

[2:31-2:36]

J: Ninguém vai acreditar nessa história.

D: Querido, quanto isso aí, relaxe, porque o pessoal acredita em qualquer coisa. Vai por mim.

Nesta cena, notamos que o primeiro dogma ressignificado no vídeo diz respeito à virgindade de Maria, mencionada no livro Mateus. Na narrativa bíblica, o autor cita o profeta Isaías e fala do cumprimento da profecia do Antigo Testamento, período anterior ao nascimento de Jesus, que diz: “A virgem ficará grávida e dará à luz um filho, e o chamarão Emanuel” (MT 1, 23).

Desde os primeiros minutos do vídeo, a opção dos roteiristas é problematizar a questão do poder exercido pela tradição cristã em seus fiéis. Porta dos Fundos quer deixar a mensagem de que a crença de tais fiéis é cega e que a suposta verdade da virgindade da mãe

\footnotetext{
${ }^{5}$ Os roteiros dos esquetes pertencentes ao vídeo Especial de Natal aqui decupados não estão na íntegra. Para fins metodológicos de análise, foram selecionados trechos considerados importantes para o trabalho.
} 
do filho de Deus é passível de contestação, pois os próprios cristãos não duvidam de uma história que, segundo o canal, oferece subsídios de sobra para ser questionada.

Ainda com foco em momentos específicos do vídeo, partimos para a cena na qual Jesus [Je] leva Maria Madalena [MM] para um jantar de apresentação com José [J] e Maria $[\mathrm{M}]:$

[6:53-7:11]

M: Jesus, [ela é] muito bonita!

MM: Obrigada!

M: Você faz o quê?

Je [interrompendo a fala de MM]: Ela trabalha em recursos humanos.

J: Em qual empresa você trabalha?

Je [com fala ofegante]: Ela é autônoma.

M: José também!

Je: Pois é, ela é que nem papai.

J: Engraçado, eu tenho impressão que conheço você de algum lugar...

Nesta cena, a crença na virgindade e castidade de Jesus é posta em xeque, uma vez que os roteiristas propõem que Jesus possui um romance com a moça e tenta, de todo modo, esconder de seus pais que ela é prostituta. Isso para que eles a aceitem como sua namorada. Dessa vez, o próprio Jesus engana seus pais. Consequentemente, a tradição cristã enganaria seus adeptos quando diz que Jesus nunca se relacionou sexualmente com uma mulher. Todavia, na primeira epístola de Pedro, o apóstolo também faz menção ao profeta Isaías para destacar que "Ele [Jesus] não cometeu pecado algum, e nenhum engano foi encontrado em sua boca." (1 PED 2, 22).

Nos últimos minutos do vídeo, a produção polemiza a cena da morte de Cristo. Jesus [Je] está deitado em uma cruz com expressões faciais preocupadas e Tibério [T], um guarda romano com martelo em mãos, está pronto para crucificá-lo. Bem diferente dos relatos bíblicos, não há pessoas assistindo. Pelo contrário, a crucificação não teve o impacto como muitos imaginam, segundo Porta dos Fundos. Vários outros momentos da cena questionam as fontes de poder da tradição bíblica, como quando Jesus pergunta acerca da procedência da madeira ou quando pede vinho para aliviar a sua dor. Nas falas finais, é a seriedade do sacrifício de Cristo que o vídeo coloca em questão:

[13:53-14:00]

[Tibério prega uma das mãos de Jesus na cruz] Je: Já foi? 
T: Doeu?

Je: Você tem mãos de fada, heim?!

T: O que eu estava tentando te falar desde aquela hora?

Precisava desse show? Desse carnaval?

Je [referindo-se a outra mão]: Vai... vai na outra.

Para a tradição cristã, a morte de Jesus trouxe vida, cura e paz a todos os indivíduos, pecadores por natureza. No livro Isaías, o profeta afirma que "Ele [Jesus] foi transpassado por causa das nossas transgressões, foi esmagado por causa de nossas iniquidades; o castigo que nos trouxe paz estava sobre ele, e pelas suas feridas fomos curados.” (IS 53, 5). De acordo com o cristianismo, a dor que Jesus sentiu na cruz serviu para que os seres da terra não precisassem passar pelo mesmo sofrimento, isto é, uma dor sentida no lugar de outras pessoas. Em linhas gerais, o cristianismo refere-se a Jesus como um inocente sacrificado imerecidamente.

Na cena mencionada, Porta dos Fundos nega o sacrifício vicário de Jesus e oferece subsídios para tensionamentos perante uma legião de adeptos ao cristianismo a partir do momento em que relativiza a dor ou sugere que Jesus não seria capaz de suportá-la. Este aspecto se expressa quando ele diz ao guarda que possui "mãos de fada" ou quando o guarda se refere ao sofrimento como show. Com isso, não somente este momento do vídeo, mas toda a produção é capaz de desconstruir uma série de sentidos dogmáticos cristãos e questionar o discurso de poder exercido pela Igreja.

Feita a análise do vídeo por meio da decupagem e transcrição de alguns trechos que permitiram a identificação de dogmas cristãos criticados, voltamo-nos agora para os comentários acerca do vídeo feitos na página do YouTube. Como explicitamos outrora, o corpus de análise é composto por 176 comentários. Por meio da ferramenta "ocorrência de palavras" do software de análise textual NVivo 10, foi possível gerar uma tabela com o índice de incidência de todas as palavras que são mencionadas nos comentários, ou seja, pudemos saber quantas vezes uma palavra específica apareceu nos comentários.

Dentre todas as palavras listadas na tabela, selecionamos aquelas que nos interessavam e estavam em consonância com a temática exposta no vídeo, bem como os dogmas (verdades) e crenças questionadas ou apropriadas por Porta dos Fundos. As palavras selecionadas e o número de incidência respectivo a cada uma são: bíblia (13); deus (118); crença (13); crente (10); cristãos (17); cristianismo (8); humor (21); jesus (55); religião (42); religiões (12); verdade (29) e vida (26). A partir destes dados oferecidos pelo NVivo 10, pudemos gerar uma 
correlação entre as palavras-chave escolhidas e as demais sentenças textuais presentes nos comentários selecionados. Um exemplo desta relação pode ser visualizado na Figura 1:

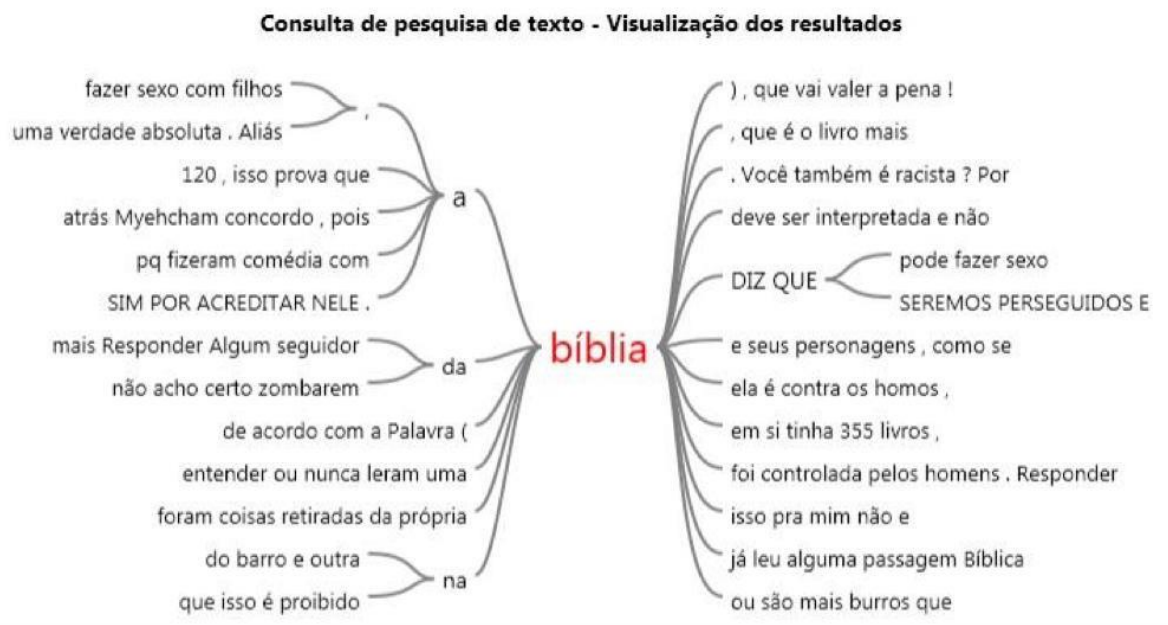

Figura 1 - Árvore "bíblia" gerada pelo software NVivo 10 Fonte - Elaborado pelos autores

Para cada palavra-chave elencada, geramos uma árvore, como visto na Figura 1. É a partir destas correlações que os comentários são analisados. De modo geral, é possível afirmar que a tematização dos comentários se orienta em torno da palavra "deus", que obteve o maior número de incidência em comparação a todas as outras palavras empregadas. Inferimos que isso se deve ao fato de o próprio vídeo repensar os modos de crença em "Deus" e ofertar aos públicos do vídeo outra narrativa a respeito do nascimento, vida e morte do "fillho de Deus", Jesus Cristo.

Notamos que os usuários que expressam sua crença em Deus e defendem sua fé nele são nomeados como "crentes" ou "cristãos", ou seja, aqueles que creem em Deus e em seu filho Jesus, bem como possuem plena convicção da existência deles. Essa crença contrasta com a não crença dos "não crentes" ou "ateus", que declaram que acreditar em "Deus" é "pura hipocrisia". Todavia, quando a verdade dos crentes (ou cristãos) é colocada em xeque, tanto pelo conteúdo do vídeo, quanto por algum comentário, estes se utilizam do "juízo final”, espécie de fim do mundo em que Deus julgará e condenará os escarnecedores, como forma de rebater a crítica. Ademais, a conversação continua e a existência - e o poder - de Deus é novamente questionada. Os cristãos são acusados de hipócritas justamente por viverem uma 
vida de apego à materialidade carnal e terrena, pois são facilmente amedrontados perante à morte ou à doença, como podemos observar nesta conversação (FIG. 2):

\section{2 semanas atrás}

Kkk quem zomba por ultimo zomba melhor. Veremos no juizo final. Temos plena convicçao da nossa fé e da Existencia do todo poderoso, ja os ateus vivem com incerteza em seu coração. Tem razao de perseguir apenas os cristãos, este é o objetivo de satanas, estas pessoas sao marionetes dele.

Responder $=2$

Ocultar respostas $\wedge$

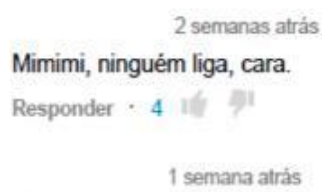

em algum momento você viu Jesus zombando dos outros ou usando de toda sua majestade para se sobressair? As pessoas cuspiam no rosto dele, zombavam dele, o crucificaram e sua atitude foi Pai perdoa-lhes porque não sabem o que fazem! Jesus ensinou se baterem no nosso rosto ofereça o outro lado, se te obrigarem a andar uma milha vai com ele duas, se te roubarem a capa de-lhe também a túnica! Falar a verdade para as pessoas é antes de tudo ama-las e não entrar numa discussāo para ver quem esta certol Devemos ser humildel Todos nós pecamos e necessitamos da misericórdia de Deus, todos nós estávamos perdidos e mesmo assim Deus nos amou e nos resgatou, assim devemos fazer aos outros, Deus nos esperou tanto

Figura 2 - Comentários ao vídeo Especial de Natal no YouTube - canal Porta dos Fundos Fonte - PORTA DOS FUNDOS, 2013

Estes comentários revelam a possibilidade que o humor de Porta dos Fundos abre para que os modos de crença em determinada verdade sejam repensados ou questionados. Os comentários a seguir apresentam a Bíblia tematizada como a "Palavra de Deus", da qual não se deve zombar ou escarnecer, uma vez que ela contém as verdades do cristianismo, ou seja, os dogmas que orientam as ações daqueles que nela acreditam (FIG. 3). Acreditar na Bíblia, então, para os cristãos, é acreditar em Deus e em Jesus, de modo que se deve viver e agir do modo como ele viveu e agiu. Vejamos a figura: 


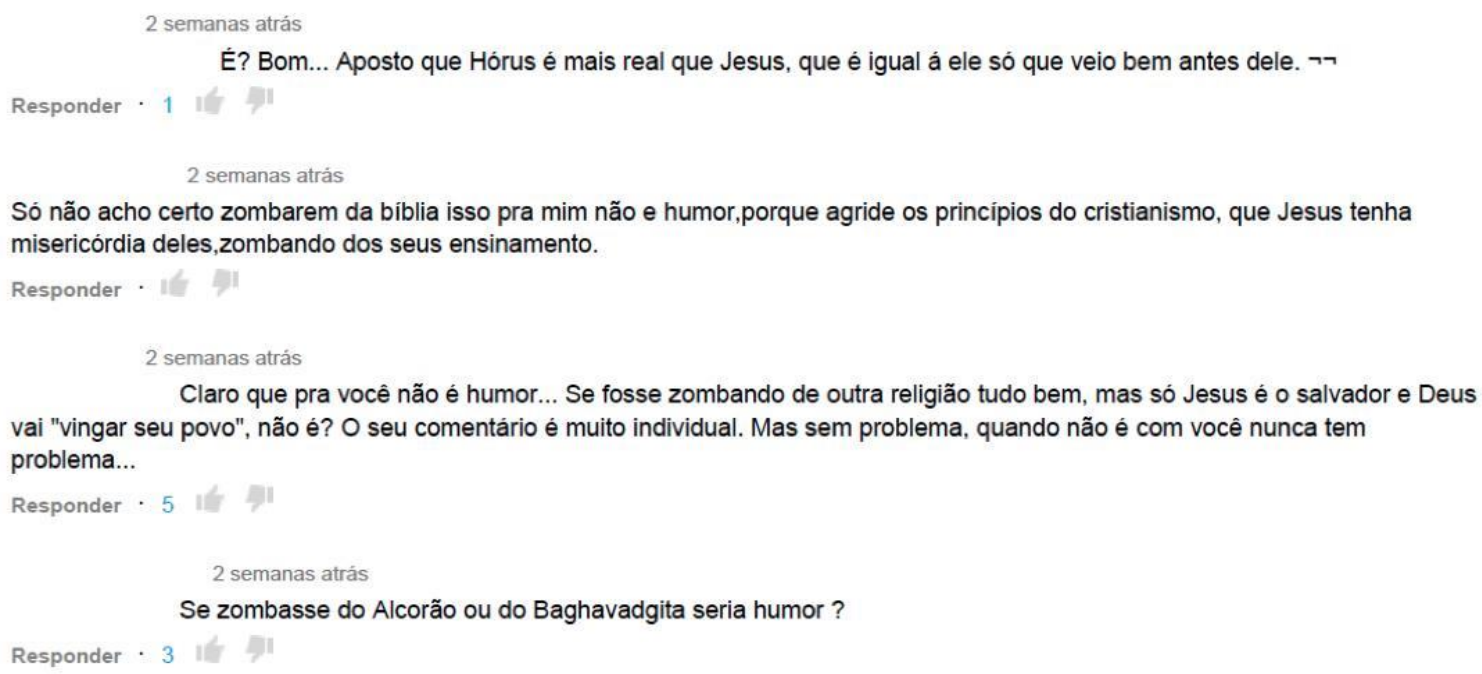

Figura 3 - Comentários ao vídeo Especial de Natal no YouTube - canal Porta dos Fundos Fonte - PORTA DOS FUNDOS, 2013

Um embate entre cristãos e não cristãos é estabelecido. Os cristãos defendem sua fé e expressam sua crença ao afirmarem que devem ser respeitados e que o humor de Porta dos Fundos deveria fazer a mesma coisa. Há uma tensão entre o que o humor pode ou não pode, entre o que ele deveria ou não deveria suscitar. Enquanto não cristãos atacam cristãos argumentando que a crença em Deus é instável ou passível de questionamento, cristãos se defendem declarando que eles possuem o mesmo direito e legitimidade em questionar os não cristãos, como podemos notar nos comentários presentes nas Figuras 4 e 5 :

Ateus, vocês não são perseguidos pelos cristãos, muito menos lhe são tirado os direitos de falar, quão pouco faltamos com falta de respeito com vocês que não acredita, segundo nossa lei, todos são iguais a perante a lei, e todos temos a liberdade de expressão, existe 5.000 religiões ai fora, por quê perseguir justo a nós cristãos? Se fosse com os mulçumanos eles cortaria a cabeça de cada um que fez o video, $e$ vocês não são ninguem para falar se é ou não verdade o que esta escrito na biblia, ai vocês vem com o papo de que nós também não somos ninguem para falar de vocês, MAS QUEM É QUE FALA DE VOCÊS? Nos defendemos isso sim, então vá encher o saco das 4.999 religiôesqje tem por ai e parem de encher a nós Cristão.

Responder

Ocultar respostas $\wedge$

2 semanas atrás

1. Os dois se perseguem, isso nunca vai acabar enquanto houver crenças diferentes.

2. O vídeo é falso e foi pros EUA defenderem o "seu petróleo".

3. Não existe 5000 religiões. Provavelmente, tem muitas mais que ainda nem sequer as pessoas sabem.

4. Não é questão de perseguição, mas uma questão de defesa . O cristianismo matou milhares de milhões, mas você ainda adora seu deus. Se você não quer ser criticado, é tão doído ignorar?

Responder . 1

Figura 4 - Comentários ao vídeo Especial de Natal no YouTube - canal Porta dos Fundos Fonte - PORTA DOS FUNDOS, 2013 
1 semana atrás

\begin{abstract}
Quem possui religião que está sempre enchendo o saco, principalmente sabendo que uma determinada pessoa não acredita em Deus.

Nós que somos Ateus, não podemos nos manifestar, pois somos recriminados, odiados, perseguidos, etc... Nós que somos ateus muitas vezes perdemos grandes amizades, empregos, promoções no trabalho, até o desprezo familiar sofremos, somos reprimidos, somos excluidos da sociedade, etc.etc...

Leia mais

Responder

1 semana atrás

É verdade, sou seguidor de Jesus, e não concordo com as afrontas de alguns cristãos que descumprem um dos principais mandamentos, amar ao próximo! Tenho amigos Ateus, gosto deles e quero o bem deles, não concordo com seu posicionamento mas respeito sua decisão! Assim como eles não concordam com o meu, mas me respeitam! E a inquisição foi um descumprimento total dos princípios de Deus, pessoas sem Deus que estiveram por trás disso, e pessoas que seguiam Jesus da maneira correta também foram perseguidos nesse evento! Eles não impuseram o evangelho de Cristo, mas as leis de sua religião, num interesse politico e econômico! Jesus nunca obrigou ninguém a nada, ele apenas ensinava e aqueles que acreditavam o
\end{abstract}

Figura 5 - Comentários ao vídeo Especial de Natal no YouTube - canal Porta dos Fundos Fonte - PORTA DOS FUNDOS, 2013

\title{
4 CONSIDERAÇÕES FINAIS
}

Neste trabalho discutimos como o humor, recurso empregado pelo canal Porta dos Fundos no YouTube questiona dogmas da religião cristã. Por meio da revisão de literatura de conceitos como dogma e riso foi possível construir um arcabouço teórico que nos permitiu analisar a empiria selecionada, atentando para aquilo que adquire um novo sentido quando debatido em comentários em resposta ao vídeo Especial de Natal veiculado neste canal. O vídeo oferta, como destacamos, significados distintos daqueles apresentados pela narrativa bíblica, de modo que esta tradução e apropriação livre, ainda que com viés crítico e satírico por parte de Porta dos Fundos, incide na comicidade presente na produção videográfica estudada.

Ao longo de comentários postados em resposta ao vídeo investigado, a liberdade de expressão é reivindicada, seja por cristãos ou não cristãos, em função da oferta de temas para conversação ou apresentação de opiniões. Desse modo, usuários/as, os/as mais diversos/as, com crenças e fés as mais distintas, podem discorrer a respeito daquilo que acreditam ou não. A análise aqui apresentada aponta para pouco diálogo entre os dois grupos, em que, por meio do embate discursivo, um vê o outro e pensa em maneiras de deslegitimar suas falas, isto é, de relativizar a verdade alheia.

Neste sentido, defendemos que o humor de Porta dos Fundos é relevante na medida em que suscita expressões de crença e defesas de fé. Sujeitos complexos e plurais engajados em defender determinadas verdades, por vezes dogmáticas, veem-se ameaçados, de certo 
modo, por um riso corretivo quando suposições sedimentadas são ressignificadas e postas em xeque.

Turner (2013) afirma que o humor revigora nossas perspectivas ao nos apresentar "formas possíveis de pensamento que a convenção, a repetição e o reforço social não nos deixam ver, e nos deixam menos propensos a aceitar as opiniões convencionais" (TURNER, 2013, p. 153). O debate suscitado pelo vídeo Especial de Natal e brevemente elucidado neste artigo mostra que a noção de "dogma", quando interpretada como "algo indubitável e inquestionável", é, como nas palavras de James (1979), algo que coordena e dota de sentido a existência de sujeitos. No entanto, cabe destacar que esta concepção de crença pelo filósofo é frágil, pois tudo pode ser tomado como verdade desde que seja útil para alguém. No entanto, o pensador reconhece que verdades são mutáveis em função de fatos que acontecem e atravessam a experiência dos sujeitos, o que os permite rever suas crenças e elaborar outras verdades. O humor incide justamente nesta operação, pois põe em suspeita concepções cristalizadas e encarnadas nas ações das pessoas.

Uma vez que o inquestionável é questionado, é o próprio ser e agir no mundo que estão em posição de abalo. Olhar para uma forma específica de humor em vídeos no YouTube, que objetiva colocar em evidência e questionar o discurso de poder exercido pelo cristianismo, remete-nos, para além de uma mudança nas maneiras pelas quais aspectos e valores tidos como invioláveis estão de fato se transformando e se deslocando atualmente, a um horizonte relativo às maneiras como os sujeitos estão dispostos a defender suas verdades em prol da manutenção de seus próprios meios de existir no mundo.

\section{REFERÊNCIAS}

1 PEDRO. In: Bíblia Sagrada, Nova Versão Internacional NVI. Belo Horizonte: Bello Publicações, 2010.

BERGSON, H. O riso: ensaio sobre a significação da comicidade. São Paulo: Martins Fontes, 2004.

CÉSAR, E. M. L. História da evangelização do Brasil. Viçosa: Ultimato, 2000.

CASTRO, João V. et al. Porta dos Fundos. Rio de Janeiro: Sextante, 2013.

DICIONÁRIO ONLINE DE PORTUGUÊS. Dogma. Disponível em: <http://www.dicio.com.br/dogma/>. Acesso em: 16 abr. 2015.

HEBREUS. 2010. In: Bíblia Sagrada, Nova Versão Internacional NVI. Belo Horizonte: Bello Publicações, 2010. 
ISAÍAS. In: Bíblia Sagrada, Nova Versão Internacional NVI. Belo Horizonte: Bello Publicações, 2010.

JAMES, William. Pragmatismo e outros textos. São Paulo: Abril Cultural, 1979. [Os Pensadores].

MATEUS. In: Bíblia Sagrada, Nova Versão Internacional NVI. Belo Horizonte: Bello Publicações, 2010.

MIDIAMAX. 2015. Porta dos Fundos é uma marca que vale R $\$ 500$ milhões. 19 abr. 2015. Disponível em: <http://www.midiamax.com.br/cultura/256155-porta-fundos-marca-vale-r-500milhoes.html $>$.

Acesso em: 23 jun. 2015.

MINOIS, G. História do riso e do escárnio. São Paulo: Editora Unesp, 2003.

PORTA DOS FUNDOS. Especial de Natal. YouTube, 23 de dezembro de 2013.

Disponível em: 〈https://www.youtube.com/watch?v=2VEI_tn090c>. Acesso em: 18 jun. 2015.

TAYLOR, C. Uma era secular. São Leopoldo: Editora Unisinos, 2010.

TURNER, S. Engolidos pela cultura pop. Viçosa: Ultimato, 2013.

YOUTUBE. 2015. Programa de parcerias. Disponível em:

<https://support.google.com/youtube/answer/72851?hl=pt-BR> Acesso em: 23 jun. 2015.

Original recebido em: 30 de setembro de 2016

Aceito para publicação em: 28 de setembro de 2017

Tiago Barcelos Pereira Salgado

Doutor em Comunicação pela Universidade Federal de Minas Gerais (UFMG). Pesquisador associado ao Núcleo de Pesquisas em Conexões Intermidiáticas (NucCon/UFMG).

\section{Bruno Menezes Andrade Guimarães}

Doutorando em Comunicação pela Universidade Federal de Minas Gerais (UFMG). Mestre em Comunicação pela UFMG. Bacharel em Comunicação Social com habilitação em Jornalismo pela Universidade Federal de Viçosa (UFV). Membro do Grupo de Pesquisa em Democracia e Justiça (Margem) e identifica-se com pesquisas relacionadas à política e sua interface com a religião e as mídias digitais. Bolsista da Fundação de Amparo à Pesquisa de Minas gerais (Fapemig).

Esta obra está licenciada sob uma Licença Creative Commons. 